\title{
Aspectos do grotesco na poesia de João Cabral de Melo Neto Zênia de Faria*
}

\author{
continua válido o fato de que largos setores da \\ lírica atual sugerem, para sua interpretação, \\ o conceito de grotesco. \\ W. Kaiser \\ (le grotesque) ce domaine ou \\ l'ambigüité est souveraine.
}

A. Karatson

Em Estrutura da lírica moderna, Hugo Friedrich (1978) cita, entre outras marcas recorrentes da lírica moderna, o feio, a decomposição, a deformação, a desumanização, o absurdo, o humorismo, o estranhamento e o grotesco - aspectos que ele denomina "categorias negativas" da lírica. Não surpreende, pois, que na obra de João Cabral de Melo Neto - uma das mais representativas da poesia brasileira contemporânea - estejam presentes todas essas "categorias", que são também apontadas por diferentes estudiosos como características do "grotesco". Tal coincidência pode ser explicada a partir de Mikhail Bakhtin, quando afirma que: "o grotesco é a forma predominante que adotam as correntes modernistas atuais". (Bakhtin, 1987, p. 45).

Concluir, a partir dessas constatações, que a obra de João Cabral é grotesca seria uma generalização inconsequente. Ao contrário, não tentar aprofundar mais a análise de tal aspecto de sua obra seria fechar os olhos para um dos segmentos vitais de sua veia poética. Esta lacuna, aliás, foi apontada pelo próprio poeta, ao afirmar que o ângulo menos analisado de sua obra era justamente certo tipo de humor em sua poesia:

O humor a que me refiro está em Morte e vida severina, está em Dois parlamentos, é uma espécie de vaia na miséria. Em Dois parlamentos ninguém tem pena do cassaco de engenho, pelo contrário, ele é até meio ridicularizado. Esse é um tipo de humor às avessas, que é o humor de Cervantes. (Massi, 1987, p. 31) (grifos meus)

\footnotetext{
* Doutora em Teoria Literária e Literatura Comparada (USP). Pós-Doutorado no Centro de Estudos Comparatistas, na Universidade de Paris III - Sorbonne Nouvelle (Paris). Professora Titular da Universidade Federal de Goiás (UFG). Email: zefirff@gmail.com
} 
Nossa leitura da obra cabralina e nossas reflexões teóricas sobre o grotesco levam-nos a crer que o que o poeta pernambucano chama de "vaia na miséria" ou de "humor às avessas" - e que pode ser encontrado em vários outros de seus poemas, além dos citados por ele próprio, na referida entrevista - abrange uma parte importante do que nós consideramos como grotesco em sua obra. Realmente, apesar de a problemática do grotesco ser extremamente complexa, devido ao fato de sua natureza, bem como de as teorias sobre o assunto serem de ordem bastante diversa, percebe-se que a obra de João Cabral de Melo Neto, examinada à luz de algumas dessas teorias, está permeada de grotesco. É o que tentaremos mostrar em nosso estudo.

O termo grotesco data do século XV, quando foi utilizado como terminus technicus para designar, como se sabe, certo tipo de decoração encontrada em Roma, durante as escavações aí feitas nessa época, e, posteriormente, em outras regiões da Itália. Desde então, o termo grotesco tem sido empregado nas mais diversas acepções e interpretado das mais diversas maneiras. Alvo de inúmeros ensaios teóricos, que tentaram definir sua estrutura ou de defini-lo como categoria estética, a noção de grotesco tem dado margem a polêmicas e a controvérsias, desde o século XVIII.

Não pretendemos, aqui, traçar a história do termo grotesco, pois, além de tal empreendimento fugir completamente de nossos objetivos, já foi realizado com sucesso, quer de modo panorâmico, quer de modo exaustivamente sistemático, por diversos estudiosos do assunto ${ }^{1}$. No entanto, como utilizaremos, em grande parte de nossas análises, algumas propostas teóricas de Bakhtin, acreditamos que algumas observações sobre a noção de grotesco - tal como esse teórico a concebe para tratar da cultura popular na Idade Média e no Renascimento, e tal como o fenômeno se manifesta em nossos dias, principalmente na literatura - sejam aqui necessárias.

Os poemas de João Cabral que analisaremos, se, por um lado, constituem uma amostragem relevante da verve grotesca de sua veia poética, por outro, são construídos a partir de elementos considerados por Bakhtin como sendo particularmente característicos do "realismo grotesco" - isto é, o "sistema de imagens da cultura cômica popular". (Bakhtin, 1987, p. 17). É o caso da imagem da boca e da temática relacionada à nutrição, ao banquete, das imagens do baixo corporal e da temática das funções fisiológicas a ele relacionadas, além da temática vida/morte. Em muitos

${ }^{1}$ Entre outros autores, ver, por exemplo, Kayser (1986); Barash (1971); Claybourough (1965). 
dos exemplos citados por Bakhtin, tais aspectos aparecem estreitamente interligados, pois, segundo ele: "O cósmico, o social e o corporal estão ligados indissoluvelmente numa totalidade nula e indivisível" (id., ibid.).

Além desses elementos indicados pelo teórico russo como caracterizadores do grotesco, e que se encontram na obra de João Cabral, muitas outras marcas do grotesco, indicadas por outros teóricos, podem ser percebidas nessa obra. Este é o caso, por exemplo, no poema "O Rio"2, do aspecto do "aniquilamento do mundo", tal como essa noção é concebida por Wolfgang Kayser (1986). Nesse poema, a noção de "estranhamento", de "mundo às avessas" - também marcas do grotesco, segundo Kayser se faz presente, não só pela equivalência constante entre homem, animal, vegetal e mineral, mas principalmente por uma certa inversão da hierarquia entre esses elementos, na qual, muitas vezes, o homem ocupa uma posição inferior à dos demais elementos da natureza que citamos.

A noção de grotesco impõe-se também, na obra do poeta pernambucano, se considerarmos um dos temas recorrentes em sua poesia, ou seja, a morte e os aspectos que lhe são contíguos: velório, defunto, funeral, cemitério. Essa temática, que pressuporia um tratamento sério, mais de acordo com as circunstâncias que a envolvem, é, com frequência, abordada pelo autor de modo irreverente, sarcástico, irônico ou humorístico. É o caso de "Velório de um comendador" (Melo Neto, 1986, p. 82), em que não apenas a circunstância - velório - é tratada com irreverência, mas, sobretudo, a própria personagem do comendador é vista de modo completamente satírico e degradante. Processos praticamente semelhantes são adotados em outros poemas que também tratam da temática da morte, como "Duas das festas da morte" (id., p. 8), "Cemitério pernambucano (Nossa Senhora da Luz)" (id., p. 260), “Congresso no Polígono das secas" (id., p. 103-11), e "Funeral na Inglaterra" (Melo Neto, 1987, p. 55-8).

Além dos aspectos citados, outros ingredientes do grotesco encontramse presentes em outros poemas esparsos ao longo da obra, entre os quais podemos citar, à guisa de ilustração: passagens de Morte e vida severina (Melo Neto, 1986, p. 203-41) e de "Festa na Casa Grande" (id., p. 112-23); "Alto do Trapuá" (id., p. 261-4). Quem pretendesse realizar um estudo exaustivo do grotesco na obra de João Cabral não poderia deixar de examinar alguns poemas de Pedra do sono - livro de influência surrealista - em que, a nosso ver, há uma profusão de imagens grotescas.

Antes de prosseguirmos, faz-se necessário definir melhor o quadro

${ }^{2}$ Todas as referências aos poemas de João Cabral de Melo Neto citados neste estudo, exceto "Retrato de Poeta” e "Funeral na Inglaterra”, serão feitas a partir da edição de 1986 (cf. bibliografia). 
deste estudo. Não é nossa intenção, aqui, tratar, de modo exaustivo, o grotesco na obra de João Cabral. A análise do grotesco em toda a sua produção poética redundaria em um trabalho que extrapolaria bastante os limites deste estudo, principalmente porque o grotesco, nessa obra, manifesta-se sob formas bastante diversificadas e em graus diversos. Por um lado, isto significa que, na obra poética de Cabral, tanto podemos encontrar poemas grotescos em sua totalidade, como simplesmente passagens, situações ou apenas imagens ou figuras grotescas. Por outro lado, isto significa que, se adotássemos algumas das classificações de grotesco, propostas por certos teóricos - grotesco realista, grotesco satírico, grotesco lúdico, grotesco absurdo, etc. -, talvez as diferentes manifestações do grotesco na obra de João Cabral pudessem ser incluídas em todos esses diferentes tipos.

Mesmo partindo-se do princípio de que a definição de um texto como grotesco - independentemente da ramificação dessa categoria em que possa ser incluído - depende de alguns pressupostos gerais básicos, a possibilidade de uma subdivisão do fenômeno grotesco em diferentes tipos é um indicador de que, o simples fato de definir um texto como grotesco, não significa que todos os textos que recebam tal denominação possuam os mesmos "ingredientes". No máximo, poder-se-ia dizer, como sugere o teórico Malcolm Griffith, que eles possuem "os mesmos traços de família" ou "uma complicada rede de semelhanças se entrecruzando e se sobrepondo" (Griffith, 1968, p. 488-9). Além disso, cada ramificação do grotesco exige, para sua análise, um aparelho teórico específico que se adapte às suas peculiaridades. Todas essas razões contribuiriam para que um estudo bem abrangente do grotesco na obra poética de João Cabral fosse além dos limites que estabelecemos para este tra-balho.

Assim, além de referências pontuais a algumas passagens de certos poemas de João Cabral de Melo Neto, que servem de ilustração às nossas considerações sobre a presença do grotesco em sua obra, limitar-nosemos, aqui, a analisar, de modo mais abrangente, três textos desse poeta. Acreditamos que a análise de tais textos nos permita dar uma ideia clara de alguns tipos de manifestações do grotesco em sua produção poética. Os poemas escolhidos, por os considerarmos particularmente representativos da temática em questão, são: "Duas das festas da morte" e "Retrato de Poeta", além de algumas passagens dos segmentos "Descoberta da Usina" e "Encontro com a Usina", do livro-poema: O Rio ou a relação da viagem que faz o Capibaribe de sua nascente à cidade do Recife (Melo Neto, 1986, p. 273-304). É por estes últimos que começaremos nossa análise. 


\section{O estranhamento do mundo em $O$ Rio ou a relação da viagem que faz o Capibaribe de sua nascente à cidade do Recife: "Descoberta da Usina"; "Encontro com a Usina"}

A visão de um mundo distorcido, de um mundo às avessas permeia a obra de João Cabral que focaliza o mundo real, particularmente o espaço nordestino. Isto é perceptível, de modo relevante, em O Rio. O que ocorre, ao longo desse poema narrativo, é que o poeta, por vários processos de equivalência (metáforas, comparações, metonímias, etc.), nivela os diferentes elementos do mundo físico: o homem, o vegetal, o mineral e, às vezes, os objetos. Com frequência, aliás, como já assinalamos, por uma subversão da ordem hierárquica, o humano encontra-se em nível inferior ao desses outros elementos. Tal desumanização ou reificação do homem e, ao contrário, tal antropomorfização ou animalização dos elementos da natureza transmitem-nos aquela impressão de estranhamento, de aniquilamento do mundo de que fala $\mathrm{W}$. Kayser, em várias ocasiões, mas, sobretudo, quando tenta definir a estrutura do grotesco:

O grotesco é o mundo alheado (tornado estranho). Mas isto ainda exige uma explicação. (...) Para pertencer a ele (o mundo alheado) é preciso que aquilo que nos era conhecido e familiar se revele, de repente, estranho e sinistro. (...) Faz parte da estrutura do grotesco que as categorias de nossa orientação do mundo falhem. (Kayser, 1986, p. 159) (grifos do autor).

Talvez, em O Rio, a noção de aniquilamento do mundo - que é percebida numa visão de conjunto da obra, graças à presença de imagens ou de situações grotescas isoladas, disseminadas ao longo do texto - tenha seu impacto diminuído, em virtude de esse texto ser um longo poema narrativo. A despeito disso, não perde o poema seu teor grotesco. $O$ ponto culminante do grotesco, nesse poema, encontra-se nos segmentos "Descoberta da Usina" e "Encontro com a Usina". As considerações de Bakhtin - que transcrevemos a seguir e que tomaremos como apoio teórico em algumas de nossas análises - podem situar bem melhor os textos de Cabral na concepção de grotesco que tomaremos aqui:

O comer e o beber são uma das manifestações mais importantes da vida do corpo grotesco. As características especiais desse corpo são que ele é aberto, inacabado, em interação com o mundo. É no comer que essas particularidades se manifestam da maneira mais tangível e mais concreta: o corpo escapa às suas fronteiras, ele engole, devora, despedaça o mundo, fá-lo entrar dentro de si, enriquece-se e cresce às suas custas. $O$ encontro do homem com o mundo que se opera 
na grande boca aberta que mói, corta e mastiga é um dos assuntos mais antigos e mais marcantes do pensamento humano. $\mathrm{O}$ homem degusta o mundo, o introduz no seu corpo, faz dele uma parte de si. (Bakhtin, 1987, p. 244).

Estas linhas de Bakthin permitem-nos considerar as referidas passagens de $O$ Rio - objeto de nossa análise - como um exemplo de "vida do corpo grotesco". Com efeito, a citação desse teórico aplica-se perfeitamente a tais textos de Cabral, desde que procedamos à inversão de algumas de suas partes, como passaremos a demonstrar. Em Cabral, "o corpo (que) escapa às suas fronteiras, (...) engole, devora, despedaça o mundo, fá-lo entrar dentro de si e enrique-se e cresce às suas custas" não é o do homem, mas o da Usina. Da mesma forma, "a grande boca que mói, corta e mastiga" é também, em última instância, a da usina. E, finalmente, não é o homem que "degusta o mundo", é o mundo, representado principalmente pela Usina, que o "degusta" e o introduz em seu corpo.

Estas constatações colocam os textos, que ora analisamos, duas vezes como grotescos. Em primeiro lugar, porque neles fica clara a subversão da ordem do universo: o homem é desumanizado, visto como coisa ou como máquina; a usina e o canavial aparecem animalizados. Em segundo lugar, porque, aí, a imagem recorrente da boca e dos demais elementos pertencentes ao mesmo campo associativo (Lisboa, 1976, p. 12) - engolir, comer, dentes, devorar, mastigar - compõem um conjunto grotesco dos mais característicos, criando uma visão estranha, deformada ou monstruosa da realidade representada.

Assim, em várias estrofes das passagens escolhidas de "Descoberta da Usina" e de "Encontro com a Usina" verifica-se um movimento cíclico de heterofagia e de autofagia de seus principais componentes:

\title{
DESCOBERTA DA USINA
}

\author{
Vira usinas comer \\ as terras que iam encontrando \\ com grandes canaviais \\ todas as várzeas ocupando. \\ O canavial é a boca \\ com que primeiro vão devorando \\ matas e capoeiras, \\ pastos e cercados; \\ com que devoram a terra \\ onde um homem plantou seu roçado; \\ depois os poucos metros
}


onde ele plantou sua casa;

depois o pouco espaço

de que precisa um homem sentado;

depois o sete palmos

onde ele vai ser enterrado.

Muitos engenhos mortos

haviam passado no meu caminho.

De porteira fechada,

quase todos foram engolidos.

Muitos com suas serras,

todos eles com seus rios,

rios de nome igual

como crias de casa, ou filhos.

Antes foram engenhos,

poucos agora são usinas.

Antes foram engenhos,

agora são imensos partidos.

Antes foram engenhos

com suas caldeiras vivas;

agora são informes

partidos que nada identifica. (Melo Neto, 1986, p. 287) (grifos meus)

O canavial é animalizado pela metáfora da "boca" e pelas ações próprias de seres animados - devorar, assaltar, sufocar, mastigar -, que ele realiza como agente da usina. Inicialmente o canavial aparece como devorador de matas, de capoeiras, de pastos, de cercados, da terra e, finalmente, do próprio homem. Em "Encontro com a Usina", de agente devorador, o canavial transforma-se, ele mesmo, em alimento devorado para saciar a avidez da usina, daquela

$$
\begin{aligned}
& \text { (...) boca maior } \\
& \text { que existe por detrás } \\
& \text { das bocas que ela plantou; } \\
& \text { que come o canavial } \\
& \text { que contra as terras soltou; } \\
& \text { que come o canavial } \\
& \text { e tudo o que ele devorou; } \\
& \text { que come o canavial } \\
& \text { e as casas que ele assaltou; } \\
& \text { que come o canavial }
\end{aligned}
$$


e as caldeiras que sufocou.

Só na Usina é que vi

aquela boca maior,

a boca que devora

bocas que devorar mandou. (id., p. 288) (grifos meus)

Essas "bocas que devorar mandou" referem-se tanto ao homem, quanto ao canavial, embora o homem, por um processo metafórico de reificação, seja reduzido a dente/máquina da Usina, ora sendo mastigado pelo canavial, ora o mastigando:

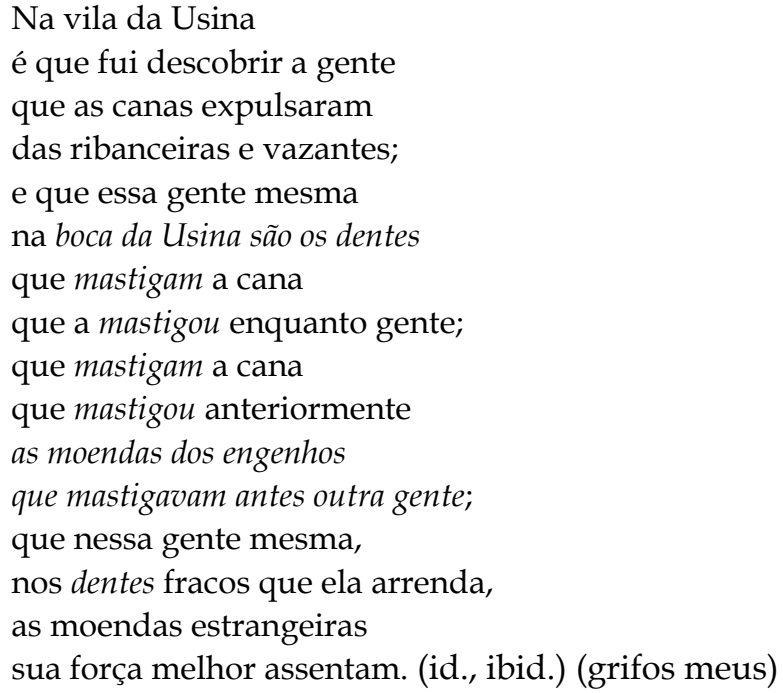

Finalmente, num movimento autofágico, assim como o canavial-boca da Usina acaba sendo devorado por aquela "boca maior", a gente-dente "com que a fábrica mastiga" acaba comendo-se a si própria:

Dentes frágeis de carne,

que não duram mais de um dia;

dentes que se comem

ao mastigar para a companhia. (id., p. 289)

Desse movimento cíclico de devoração, só a Usina mantém o papel de agente absoluto, ilesa, nunca devorada, sempre devorando, triturando, nivelando vegetal e homem. Aqui a reificação do homem é completa. Do homem, satisfeita a avidez da Usina, só resta o bagaço. Cana e homem têm o mesmo destino: bagaço: 
vi homens de bagaço

enquanto por ali discorria;

vi homens de bagaço

que morte úmida embebia. (id., ibid.)

Não resta dúvida de que a Usina, com sua proliferação de bocas autofágicas e heterofágicas, com seus "dentes de carne", em sua voracidade exacerbada, devorando tudo ao redor, triturando tudo, reduzindo tudo a bagaço, é o protótipo da figura grotesca. O que diz um outro teórico, L. B. Jennings a respeito da figura grotesca só vem reforçar a noção de alienação, de estranhamento a que aludimos anteriormente, e que se observa nos segmentos analisados:

É verdade (...) que figuras grotescas parecem sair de um mundo no qual nossos padrões de proporções e de propriedade não se aplicam e estão provavelmente sendo solapados ativamente. Nesse sentido, podemos falar de um princípio de caos em ação. (Jennings, 1963, p. 13-4) (tradução minha).

Outro estudioso do grotesco, P. Thomson, por sua vez, no capítulo sobre as funções do grotesco, explica o mecanismo através do qual o grotesco atua sobre o leitor:

O efeito de choque do grotesco pode (...) ser usado para confundir e desorientar o leitor, para paralisá-lo, para sacudi-lo com uma perspectiva radicalmente diferente, inquietante. (Thomson, 1972, p. 58) (tradução minha)

E, ainda:

A colocação inesperada de elementos familiares da realidade, sob uma luz peculiar e perturbadora, frequentemente aparece como um agrupamento de coisas disparates e inconciliáveis, que por si sós não despertariam nenhuma curiosidade. (id., p. 59) (tradução minha)

Thomson denomina "alienação" tal efeito do grotesco. E, nas passagens de $O$ Rio que analisamos, tal deve ser o efeito causado no leitor, ao ver as imagens familiares do cassaco de engenho, do canavial e da usina sob o ângulo grotesco da trituração, da destruição do homem e do espaço que o cerca, pela voracidade ávida da usina-monstro. É fácil ver, neste caso, que o grotesco desempenha a função, aqui, de uma arma de denúncia apontada contra o sistema social dominante no nordeste. 


\title{
"Retrato de poeta" e o "baixo-corporal"
}

\author{
O poeta de que contou Burgess, \\ que só escrevia na latrina, \\ quando sua obra lhe saía \\ por debaixo como por cima, \\ volta sempre à lembrança \\ quando em frente à poesia \\ meditabunda que \\ se quer filosofia, \\ mas que sem a coragem e o rigor \\ de ser uma ou outra, joga e hesita \\ ou não hesita e apenas joga \\ com o fácil, como vigarista. \\ Pois tal meditabúndia \\ certo há de ser escrita \\ a partir de latrinas \\ e diarreias propícias. (Melo Neto, 1976, p. 10) (grifos meus)
}

Em seu livro sobre Rabelais, Bakhtin menciona a tese defendida por numerosos autores alemães do século XIX, sobre a origem alemã da palavra "carnaval" que, etimologicamente, significaria: "Karne" ou "Karth" - "lugar santo", isto é, a comunidade pagã, os deuses e seus servidores - e "val" ou "wal" - "morto" ou "assassinado": logo, "procissão de deuses mortos, destronados." (Bakhtin, 1987, p. 345)

As imagens do poeta e da poesia, que João Cabral nos apresenta em "Retrato de poeta", estão bem de acordo com a significação de carnaval acima lembrada. Este poema é inteiramente construído a partir do que Bakhtin considera "o princípio artístico essencial do realismo grotesco", ou seja, o princípio do "rebaixamento". Segundo tal princípio, "todas as coisas sagradas e elevadas aí (no realismo grotesco) são reinterpretadas no plano material e corporal". (id., p. 325)

Em outras palavras, ao construir o poema "Retrato de poeta", a partir do princípio de "rebaixamento", João Cabral desloca tanto o poeta - considerado, em diferentes momentos da história da cultura, de um ponto de vista totalmente positivo, como um ser nobre, superior, elevado -, quanto a poesia - frequentemente vista como um tipo de produção literária pertencente a um nível sublime, nobre, sagrado -, para um plano inferior, terra-a-terra, menos elevado. Assim, o tratamento que Cabral dá à temática poeta/produção poética permite-nos afirmar que, para ele, poesia e 
poeta - pelo menos um certo tipo de poesia e um certo tipo de poeta - são "deuses destronados".

Tal postura do poeta pernambucano, explicitada de modo satírico e escatológico em "Retrato de Poeta", coloca o autor na mesma posição dos porta-vozes da cultura popular do passado: "A cultura popular do passado esforçou-se sempre, em todas as fases de sua longa evolução em vencer pelo riso, em desmistificar, em traduzir na língua do 'baixo' material e corporal (na sua acepção ambivalente), os pensamentos, imagens e símbolos cruciais das culturas oficiais." (id., p. 345-6).

Uma análise mais detalhada do poema "Retrato de poeta" colocará melhor em evidência os aspectos aos quais aludimos nas páginas precedentes, bem como outros que não citamos, mas que também contribuem para definir o texto em questão como grotesco.

Antes de passarmos, porém, à análise concreta desse poema, achamos importante lembrar, aqui, um dos pontos básicos da teoria de Bakhtin sobre o grotesco. Trata-se da oposição existente entre a representação do corpo segundo as normas clássicas da antiguidade e a representação do corpo grotesco que se afasta dessas normas. O corpo "clássico" seria o corpo perfeito, completamente isolado do mundo exterior. Isto quer dizer que os clássicos ignoravam todas as partes do corpo que são protuberantes ou que possuem orifícios que impliquem uma relação entre o corpo e o mundo e, consequentemente, as funções orgânicas relativas a essas partes: a copulação, a gravidez, o parto, a nutrição, a defecação etc.

No poema que ora comentamos, João Cabral transpõe para o plano material e corporal ligado ao "baixo corporal", logo, ao corpo grotesco, tanto as ações, a postura do poeta, quanto sua produção poética. Vejamos que recursos ele utiliza, para obter tal resultado.

O poeta utiliza uma série de termos pertencentes ao domínio escatológico. Assim, além de "latrina" e de "diarreias", objeto e resultado de função fisiológica claramente pertencentes ao citado domínio, encontramos outros termos, cuja conotação, orientada pelo contexto, os situa igualmente no mesmo plano. Tal é o caso da palavra "obra", em que o poeta joga com duas acepções do termo: composição literária e excremento humano. A relação entre "a obra sua que lhe saía / por debaixo como por cima" e a "poesia meditabunda que / se quer filosofia" é reforçada pela ambiguidade que se instala nas palavras meditabunda/meditabúndia. Tal ambiguidade não provém do sentido literal dessas palavras, nem de sua etimologia, que, na realidade, conduzem apenas aos sentidos: "que medita profundamente" ou "poesia profunda". A ambiguidade é oriunda, antes, de uma falsa etimologia (o espiritual ligado ao baixo corporal) 
que, na língua portuguesa, as palavras sugerem, e que, no contexto do poema, leva inevitavelmente a uma conotação pejorativa.

Tal postura de Cabral sobre a "poesia meditabunda que se quer filosofia", desmitificando um determinado tipo de poesia, reitera, de certa forma, posicionamentos anteriores do poeta a esse respeito, principalmente aquela que adotou ao escrever o poema "Antiode". Nesse poema, a posição do poeta é definida, desde o início, ao acrescentar ao título o seguinte subtítulo: “(contra a poesia profunda)". Em "Antiode", João Cabral, num processo de decomposição da metáfora poesia=flor, termina por nivelar poesia, flor e fezes, depois de esvaziar a palavra flor (e, consequentemente, de dessacralizar a linguagem poética) de todas as conotações elevadas e nobres que lhe eram tradicionalmente atribuídas, e de reduzi-la, no contexto, a uma simples palavra desmetaforizada. Em "Antiode", como em "Retrato de poeta"-, o autor recorre frequentemente ao orgânico, a um léxico relacionado ao material e ao "baixo corporal", num verdadeiro processo de "rebaixamento" - como ele mesmo afirmava: "palavras impossíveis de poema" Antiode (Melo Neto, 1986, p. 337) -, para referir-se à poesia, como se pode verificar, na seguinte estrofe:

Delicado, evitava

o estrume do poema,

seu caule, seu ovário,

suas intestinações. (id., p. 333) (grifos meus)

Ou ainda:

Poesia, te escrevo

Agora; fezes, as

Fezes vivas que és. (id., p.336) (grifos meus)

A ambiguidade - marca essencial do grotesco - instaura-se, ainda, no poema "Retrato de Poeta", através de outros elementos: ora através das construções em que o alternativo "ou" está presente ("ser uma ou outra", "joga e hesita ou não hesita e apenas joga"), ora através da escolha do léxico "hesita", palavra ambígua por excelência, visto que já traz em si a noção de indecisão, de indefinição. Outro aspecto de teor grotesco a se considerar seria o motivo da máscara - motivo grotesco - implícito tanto na alusão à poesia: ela não é filosofia, mas "se quer filosofia" -, quanto ao poeta, equiparado a "vigarista": aquele que se faz passar por outro.

A maior parte das observações que fizemos sobre o poema de que nos ocupamos deixa claro o caráter de "desarmonia" nele existente. Segundo Thomson, esta é uma das marcas recorrentes do grotesco, e uma de suas 
formas de manifestação é o conflito de elementos díspares. Aqui, como é óbvio, a desarmonia consiste, fundamentalmente, na apresentação da imagem do poeta e da poesia - considerados normalmente como sendo de caráter nobre e elevado, como já sublinhamos - através de construções em que predomina um léxico denotativa ou conotativamente de teor escatológico. Esse poema apresenta, também, o caráter de anormalidade, ou seja, aquilo que, fugindo às normas aceitas e aos padrões estabelecidos, pode despertar reações opostas - por exemplo, de repugnância e de divertimento - ao mesmo tempo. A anormalidade, aqui, consistiria, não apenas na utilização de termos pertencentes ao domínio escatológico para falar de poeta e de poesia, mas no próprio fato de serem utilizados tais termos para escrever poesia. Os comentários de Thomson a respeito da natureza anormal do grotesco são bastante esclarecedores a esse respeito:

A natureza essencialmente anormal do grotesco, e a maneira direta e radical como tal anormalidade é apresentada, talvez seja responsável, mais do que qualquer outra coisa pela não rara condenação do grotesco como ofensivo e incivilizado, como uma afronta à decência e um ultraje à "realidade" e à "normalidade" - ou, expresso na linguagem menos obviamente moralista da crítica estética, como uma distorção de mau gosto e gratuita ou um exagero sem sentido. (Thomson, 1972, p. 26) (tradução minha)

\section{"Duas das festas da morte": a ambivalência e o choque de incom- patíveis}

Recepções de cerimônia que dá a morte; o morto, vestido para um ato inaugural; e ambiguamente: com roupa do orador e a da estátua que se vai inaugurar.

No caixão, meio caixão meio pedestal, o morto mais se inaugura do que morre; e duplamente: ora sua própria estátua ora seu próprio vivo, em dia de posse.

Piqueniques infantis que dá a morte: os enterros de criança no Nordeste: reservados a menores de treze anos, Impróprios para adultos (nem o seguem). Festa meio excursão meio piquenique, ao ar livre, bom para o dia sem classe; 
Nela, as crianças brincam de boneca,

e, aliás, com uma boneca de verdade. (Melo Neto, 1986, p. 8)

"Um conflito não resolvido de incompatíveis em ação e reação"; "o ambivalentemente anormal". (Thomson, 1972, p. 27) (tradução minha). À luz dessas definições complementares de grotesco, propostas por P. Thomson, a leitura do poema "Duas das festas da morte" não deixa dúvida quanto à sua natureza grotesca. A noção de "choque de incompatíveis" e de "ambivalência" é verificável a partir do próprio título. "Festas" e "morte" são situações e termos que, em geral, se excluem totalmente, pelo menos no Ocidente. E, quando se encontram reunidos, como no caso do poema citado, despertam no leitor uma reação um tanto ou quanto ambígua. O poema, composto por duas estrofes, trata, em cada uma delas, de um tipo particular de "festa da morte": o ato fúnebre de um adulto e o ato fúnebre de uma criança.

A ambiguidade da reação provocada pelo título permanece ao longo do poema, já que todo ele é construído a partir da aproximação de elementos que se opõem e se excluem. Assim, o primeiro verso, "Recepções de cerimônia que dá a morte", acentua o impacto causado pelo título, pois ambos os termos que compõem esse verso têm aí seu sentido ampliado e confirmado: as "festas" são recepções de cerimônia, e o verbo "dar" define a morte como promotora de tais recepções.

A primeira parte do poema apresenta - além da presença de "recepções de cerimônia", no primeiro verso - todo um aparato de festa, pela referência a: ato inaugural, roupa de orador, estátua que se vai inaugurar, dia de posse. Ao mesmo tempo, encontramos, aí, referências à própria circunstância fúnebre: "morte", "morto", "caixão". O choque de incompatíveis e a ambivalência se instauram devido ao fato de os aspectos relativos à festa e à morte não se encontrarem separados uns dos outros. Ao contrário, devido à forma de estruturação da estrofe, tais aspectos se justapõem, se interpenetram, se completam.

O morto aparece, ao mesmo tempo, como o "orador" e como a "estátua" que se vai inaugurar. A fusão entre eles dá-se, inicialmente, por meio de suas roupas de festa. Mas a superposição estátua/morto processa-se porque a rigidez cadavérica e a imobilidade inerentes aos mortos os tornam semelhantes a uma estátua. As estátuas, da mesma forma que bonecas, manequins ou outras reproduções humanas que tenham o corpo enrijecido são frequentemente consideradas como elementos marcadamente grotescos, sobretudo quando representam a transformação de um ser vivo, animado, em um objeto inanimado.

O caixão, objeto característico de cerimônia fúnebre, tem sua ambi- 
valência claramente explicitada: "meio-caixão, meio-pedestal". A fusão de tais aspectos díspares cria um objeto grotesco por sua heteróclise. $\mathrm{O}$ pedestal, objeto geralmente destinado a apresentar um elemento decorativo ou uma estátua para serem admirados, completa a imagem do morto/ estátua que se vai "inaugurar".

Nos quatro últimos versos da primeira estrofe, há uma concentração de ambivalências, na medida em que o que deveria ser a imagem do fim (morte) apresenta-se como começo (inauguração, dia de posse). A ambivalência e o choque de incompatíveis são reforçados pelos elementos enfatizadores "mais" ("mais se inaugura do que morre") e "duplamente". Além disso, a oposição entre "sua estátua/seu próprio vivo, em dia de posse" (objeto inanimado/ser humano iniciando uma atividade) é negada pela presença das conjunções, "ora (...), ora" , que, apesar de alternativas, funcionam como marcas de permanência de ambos os aspectos que, em princípio, deveriam se excluir.

Na segunda parte do poema, da mesma forma, o desconforto do leitor surge desde o primeiro verso, pela reunião de "piqueniques infantis" - que implica a ideia de alegria, de descontração - com a "morte" que, ao contrário, anula os efeitos de euforia contidos na imagem de "piqueniques infantis". Mais uma vez, aqui, a morte é a promotora da festa. $\mathrm{O}$ impacto é maior, quando constatamos que a expressão "piqueniques infantis" refere-se aos "enterros de crianças no Nordeste".

Toda a estrofe, a partir do terceiro verso, é orientada no sentido da festa, do espetáculo. Em primeiro lugar, pela linguagem de censura, geralmente reservada aos espetáculos: "reservados a menores de treze anos", "impróprio para adultos". Aqui, a explicação parentética - "(nem o seguem)" - choca pelo desinteresse e pela indiferença com que o fato é tratado pelos adultos, principalmente se se considerar que "reservados a menores de treze anos" é, certamente, uma alusão à mortalidade infantil. Em segundo lugar, pela especificação do tipo de entretenimento: "festa meio excursão meio piquenique". A ideia de descontração contida em "piquenique", a referência a "excursão", além de ampliarem a noção de recreio", introduzem a noção de "visita a um lugar interessante", conotações essas reforçadas pelas indicações "ao ar livre", "bom para dia sem classe". A impressão de lazer, de descompromisso, presente nesses aspectos, é completada pela referência ao tipo de brinquedo utilizado: "as crianças brincam de boneca".

Excetuando-se os dois primeiros versos desta segunda estrofe, deixamo-nos levar pela imagem de lazer, de alegria, de descontração que permeiam esta parte do poema, até que o último verso - "aliás, com uma 
boneca de verdade" - nos recoloque no contexto inicial do poema: a "boneca de verdade" não é nada menos do que a criança que vai ser enterrada.

Além do "conflito de incompatíveis", as noções de lazer, de festa, de piqueniques utilizadas para se referir a enterro e morte, a presença de "boneca" - elemento grotesco da mesma natureza que estátua (objeto inanimado) - enfatizam o teor grotesco desta segunda parte do poema.

Apesar de esse poema tratar de "festas de morte", uma de um adulto e outra de uma criança, o tom de cada uma das partes é bastante diferente.

Na primeira parte, sente-se perfeitamente a veia satírica do poeta contra a aparência fútil de uma cerimônia fúnebre. Os elementos escolhidos para apresentar o funeral como um momento festivo interessam, sobretudo, pela aura de vaidade humana, de espetáculo que sugerem. Entre esses, chamamos a atenção para o caixão "meio caixão meio pedestal" e para a "estátua que se vai inaugurar". Se a fusão de elementos díspares cria o grotesco, a veia satírica do poema também é, aí, demonstrada, uma vez que o aspecto festivo acentua, sobretudo, o lado da vaidade humana presente nos aparatos que acompanham as festividades. Não se trata apenas de festa, mas de festa onde a promoção do indivíduo, sua busca de admiração, de perpetuação da sua glória são os aspectos dominantes. Daí, a importância da referência ao caixão, "meio caixão meio pedestal", a "orador", a "ato inaugural", a "dia de posse" e a "estátua". A estátua não é, geralmente, erigida para perpetuar a memória de um morto ou para louvar, engrandecer um ser vivo digno de admiração? Aqui, a relação "morto/estátua que se vai inaugurar/orador" deixa patente a ideia de autopromoção.

Na primeira parte, é, pois, clara a visão da festa como um acontecimento em que se coloca em evidência um indivíduo para sua promoção, por causa dos personagens, objetos e tipos de atividades festivas escolhidos. Na segunda parte, ao contrário, fica patente a inconsciência infantil, que não distingue uma cerimônia fúnebre de um piquenique, um cemitério de um lugar onde se faz uma excursão ao ar livre - ou se aproveita um dia sem classe -, ou mesmo, ainda, que não distingue uma criança morta de uma boneca. Ao estabelecer esta diferença entre as duas partes do poema, o autor, realmente, salienta dois modos específicos de se apreender o homem e a criança. Para o adulto, todas as ocasiões são boas para se promover socialmente, até mesmo o momento de seu funeral. Para a criança, todas as ocasiões são motivo de brincadeira, de divertimento. 
Bakhtin insiste em que o realismo grotesco, isto é, "o sistema de imagens da cultura cômica popular da Idade Média e do Renascimento, em todas as suas manifestações," contém um caráter renovador, regenerador extremamente positivo, apesar dos aspectos negativos a ele inerentes: baixo corporal, vocabulário obsceno e escatológico, circunstâncias sérias e personagens de grau hierárquico superior tratadas de modo satírico ou pelo processo de rebaixamento. Em muitos dos exemplos citados pelo referido teórico, tais aspectos aparecem estreitamente interligados, pois, como já lembramos, a seu ver, "o cósmico, o social e o corporal são indissoluvelmente ligados, numa totalidade viva e indivisível. É um todo alegre e benfazejo ". (Bakhtin, 1987, p. 17).

O verdadeiro grotesco, para ele, esforça-se, aliás, para exprimir em suas imagens:

o devir, o crescimento, o inacabamento perpétuo da existência: é o motivo pelo qual ele dá nas suas imagens os dois polos do devir, ao mesmo tempo o que parte e o que está chegando, o que morre e o que nasce; mostra dois corpos no interior de um único, a germinação e a divisão da célula viva, (...) não resta jamais um cadáver, (...) a velhice está grávida, a morte está prenhe, tudo o que é limitado, característico, fixo, acabado, precipita-se para o "inferior" corporal para aí ser refundido e renascer de novo. (id, p. 46).

Ainda segundo Bakhtin, o grotesco degenerou a partir do momento em que desvinculou sua origem da praça pública, tornando-se pura tradição literária. Assim, o que resta do realismo grotesco na literatura moderna são apenas alguns "destroços grotescos": na maioria dos casos, "trata-se de imagens grotescas que perderam ou debilitaram seu polo positivo, sua relação com um universo em evolução". (id., p. 21).

Da mesma forma, o riso grotesco perdeu seu caráter positivo. Acreditamos que o que Bakhtin comenta sobre o princípio do riso, no romantismo, possa também ser aplicado à literatura do século XX: "o riso se atenua, e toma a forma de humor, ironia ou sarcasmo. Deixa de ser jocoso e alegre. $\mathrm{O}$ aspecto regenerador e positivo do riso reduz-se se ao mínimo". (id., p. 33) (grifo do autor).

Nos textos de João Cabral, por nós analisados - e que contêm vários dos aspectos negativos, característicos do grotesco - , fica patente o fenômeno da degeneração do grotesco na literatura moderna, citado por Bakhtin. Com efeito, não resta dúvida de que os três textos analisados despertam uma reação ambivalente, diferente em cada caso. Em O Rio, é o arrepio de horror aliado ao riso amargo da ironia, ou ao riso cruel da sátira. Em "Retrato de poeta", o riso do divertimento se mistura à indig- 
nação, à repugnância. Em "Duas das festas da morte", o riso da sátira se contrapõe ao horror ou à tristeza natural que provoca a morte.

Porém, apesar da ambiguidade e da ambivalência, o que predomina nessas manifestações de grotesco, como sugere Bakhtin, é o polo negativo, é a desesperança, é a degradação. Nas citadas passagens de $O$ Rio, a imagem final, que permanece, é a do homem como bagaço, é a imagem da trituração social, enfim, a imagem da decomposição - tão característica do grotesco - sem possibilidade alguma de recuperação para o homem. Em "Retrato de poeta", nada resta do sentido regenerador do vocabulário escatológico, obsceno, utilizado no realismo grotesco. Aqui, o que esse vocabulário acrescenta é antes de tudo uma nuance destruidora, degradante, puramente negativa. Poderíamos nos referir a "Duas das festas da morte" como um exemplo de mort joyeuse (morte alegre). As palavras podem ser empregadas, mas seu sentido já não é o mesmo com que eram utilizadas no sistema de imagens da cultura cômica popular da Idade Média e do Renascimento. No realismo grotesco, a morte é isenta de qualquer nuance negativa, trágica, aterrorizante porque é uma etapa indispensável ao processo de expansão e de renovação do povo, porque é a outra face do nascimento. Não se pode dizer que se possa perceber algum desses aspectos em "Duas das festas da morte". O que, em última instância, se depreende desse poema é que a vida e a morte, dependendo do ângulo em que sejam observadas, podem apresentar semelhanças contundentes. As diferentes passagens examinadas levam-nos a acreditar que o grotesco, em muitas de suas formas, pode ser visto como uma expressão apropriada para exprimir a natureza problemática da existência. Feitas essas últimas observações, que condensam os resultados das análises que fizemos do grotesco na obra de João Cabral de Melo Neto, concluiremos este estudo, fazendo nossas as palavras de Bakhtin sobre o grotesco "degenerado", tal como, a nosso ver, ele se apresenta na literatura contemporânea:

Nesses casos, apesar das diferenças de caráter e orientação, a forma do grotesco carnavalesco cumpre funções semelhantes; ilumina a ousadia da invenção, permite associar elementos heterogêneos, aproximar o que está distante, ajuda a liberar-se do ponto de vista dominante sobre o mundo, de todas as convenções e elementos banais e habituais, comumente admitidos; permite olhar o universo com olhos novos, compreender até que ponto é relativo tudo o que existe, e portanto permite compreender a possibilidade de uma ordem totalmente diferente do mundo. (id., p. 30). 


\section{Referências bibliográficas}

BAKHTIN, Mikhail (1987). A cultura popular na Idade Média e no Renascimento. O contexto de François Rabelais. Trad. Yara Frateschi Vieira. São Paulo/Brasília: HUCITEC/Editora da UnB.

BARASCH, Frances (1971). The grotesque: a study in meanings. The Hague: Mouton.

CLAYBOUROUGH, Arthur (1965). The grotesque in english literature. Oxford: Clarendon.

FRIEDRICH, Hugo (1978). Estrutura da lírica moderna. (Da metade do século XIX a meados do século XX). Trad. Marise M. Curioni e Dora F. da Silva. São Paulo: Duas Cidades.

GRIFFITH, Malcolm (1968). “Theories of the grotesque”. In: ZAHAREAS, A. N. (Org.). Ramón Del Valle-Iclán. Nova York: Las Americas Publishing Co.

JENNINGS, Lee Byron (1963). The ludicrous demon: aspects of the grotesque in german post-romantic prose. Berkeley: University of California Press.

KAYSER, Wolfgang (1986) O grotesco: configuração na pintura e na literatura. Trad. Jaime Guinsburg. São Paulo: Perpectiva.

LISBOA, Francisco da Silva (1976). Pequeno vocabulário de linguística moderna. São Paulo: Companhia Editora Nacional.

MASSI, Augusto (1987). "A genealogia de Cabral" (entrevista concedida por J.C.de M. Neto a Massi). In: Leia. n. 110, dezembro.

MELO NETO, João Cabral (1986). Poesias completas: 1940-1965. 4. ed. Rio de Janeiro: José Olympio.

(1985). Museu de tudo. 2. ed. Rio de Janeiro: José Olympio. (1987). Crime na calle relator. Rio de Janeiro: Nova Fronteira.

THOMSON, Philip (1972). The grotesque. London: Methuen.

Recebido em maio de 2011.

Aprovado em julho de 2011.

\section{resumolabstract}

\section{Aspectos do grotesco na poesia de João Cabral de Melo Neto}

Zênia de Faria

Este artigo tem como objetivo analisar alguns poemas de João Cabral de Melo Neto, à luz de algumas teorias do grotesco, particularmente as de Bakhtin e de Kayser, tentando mostrar a presença dessa "categoria negativa" na obra do referido poeta.

Palavras-chave: João Cabral de Melo Neto, grotesco, categorias negativas da lírica 


\section{Aspects of the grotesque in João Cabral de Melo Neto's poetry}

Zênia de Faria

This paper aims to analyse some poems of João Cabral de Melo Neto in the light of some theories of the grotesque, particularly those of Bakhtin and Kayser, trying to point out the presence of this "negative category" in the work of this poet.

Key words: João Cabral de Melo Neto, grotesque, negative categories of lyrics

Zênia de Faria - "Aspectos do grotesco na poesia de João Cabral de Melo Neto". Estudos de Literatura Brasileira Contemporânea, n. 38. Brasília, julho-dezembro de 2011, p. 213-232. 